\title{
EDITORIAL
}

\section{'Rac'-ing upstream to treat rheumatoid arthritis}

\author{
Gary S Firestein* \\ See related research by Abreu et al., http://arthritis-research.com/content/12/1/R2
}

\begin{abstract}
Signal transduction pathways regulate the production and function of many cytokines implicated in immunemediated diseases. Targeting these enzymes with small molecule inhibitors represents a fertile field for the treatment of rheumatoid arthritis. Recent successes with compounds that block upstream kinases suggest that proximal members of the signaling cascades, such as Rac and other Rho family enzymes, might have therapeutic potential. Balancing efficacy and toxicity, however, remains a significant challenge that will require careful evaluation.
\end{abstract}

Protein-based therapeutics for rheumatoid arthritis have limitations despite improved clinical outcomes. In addition to expense and the need for parenteral administration, a significant percentage of patients do not have robust responses. Intracellular signaling molecules, such as members of the Rho family [1], represent an attractive alternative because the compounds are often orally bioavailable and can block numerous proinflammatory mediators simultaneously.

Targeting signal transduction, however, has been an exercise in frustration until recently. The p38 mitogenactivated protein kinase saga is emblematic of these problems [2]. Despite abundant preclinical data supporting the utility of p38 inhibitors, benefit has been marginal at best [3]. It is important to recognize that success in biologics also did not come with the first attempt. Numerous failures preceded the advent of TNF blockers, including anti-CD4, anti-CD5 and anti-CD52 antibodies, IL-2-diphtheria toxin fusion protein, IFNy, IL-2, and several others. Clinical efficacy for JAK and Syk inhibitors demonstrated in recent years crossed the Rubicon for signaling-directed therapeutics $[4,5]$. The

*Correspondence: gfirestein@ucsd.edu

Division of Rheumatology, Allergy and Immunology, University of California, San Diego School of Medicine, 9500 Gilman Drive, Mail code 0656, La Jolla, CA 92093-0656, USA question now is not whether some of these agents can be effective; rather, it is whether the toxicity and side effects will be acceptable in a world where biologics have an advantageous therapeutic index.

A distinguishing feature of the encouraging interventions (Syk, JAK, and perhaps c-Kit) compared with p38 inhibitors is that the former targets are proximal in the signaling cascade. Going upstream can be risky, since each enzyme casts a broader penumbra of effects than a downstream target. This increases the potential for both benefit and toxicity. Risk, however, can be managed; lack of efficacy cannot.

This lesson is being exploited by going far upstream using therapeutics that inhibit the Rac proteins. These signaling enzymes, unlike the classical protein kinases that phosphorylate various transcription factors, are GTPases in the Rho family [6]. They regulate a vast array of functions, including cell movement, proliferation, adhesion, and phagocytosis. Many of these functions result from the subsequent activation of downstream protein kinases, such as the mitogen-activated protein kinase family. Blocking Rac proteins, such as Rac1, could potentially suppress many mechanisms implicated in rheumatoid arthritis.

Tak and colleagues approached this problem with a peptide inhibitor in order to explore in vitro and in vivo effects of Rac1 inhibition [1]. The peptide decreased production of key cytokines like IFN $\gamma$, TNF, and IL-17 by cultured $\mathrm{T}$ cells. They also examined the peptide's effect in collagen-induced arthritis, a standard mouse model of rheumatoid arthritis [7].

The use of peptide therapeutics in vivo is fraught with problems, such as a short half-life (often only minutes) and limited access to the intracellular space where the target actually resides. Despite this limitation, a modest decrease in paw swelling was observed along with a lower anti-type II collagen antibody titer. Interestingly, no significant effect was observed on the clinical arthritis scores or histologic evidence of joint inflammation and damage. If therapy was delayed until after disease was established, a nonsignificant trend toward decreased paw swelling was noted.

Several aspects of the study warrant comment. The lack of effect on clinical scores is interesting, as this usually 
tracks with paw swelling. These two endpoints, however, evaluate somewhat distinct phenomena. The former measures edema or tissue hyperplasia in a single joint (usually the ankle), while the latter determines the sum of the total number of active joints. It is possible to have relatively mild arthritis (and minimal swelling) with a high clinical score. Conversely, severe disease in the ankles but nowhere else could also lead to disparate outcomes. The two indices of disease can thus provide complementary information. In this case, the lack of effect on joint destruction and synovial histology suggests that the Rac1 inhibitory peptide might be acting through vascular leakage and tissue edema rather than immune cell infiltration into the joint.

A second important point is that animal models are an imperfect representation of rheumatoid arthritis. The kinetics of the synovial signaling pathway in mice is compressed compared with human disease, and the specific kinases engaged can vary from model to model [8]. Animal data must therefore be interpreted with some caution. Nevertheless, results for the Rac1 inhibitory peptide offer a signal of efficacy even though they probably underestimate the potential benefit. A therapeutic agent with a longer blood half-life that is also optimized for cell penetration could give substantially better results. The safety of blocking Rac1 cannot be accurately gauged with the peptide for the same reasons.

Overall, the future looks brighter for blocking signal molecules than it did a few years ago. With the plethora of potential targets, such as Rac, and armed with information on the biology of upstream rather than downstream molecules, there is renewed optimism for developing new therapeutics for rheumatoid arthritis.

Abbreviations

IFN - interferon; IL = interleukin; TNF = tumor necrosis factor.
Acknowledgement

Supported in part by NIH grants R01AI070555, R01Al067752, and R01AR47825.

Competing interests

The author declares that he has no competing interests.

Published: 24 February 2010

\section{References}

1. Abreu JRF, de Launay D, van Hennik PB, van Stalborgh AM, ten Klooster JP, Sanders MW, Reedquist KA, Vervoordeldonk MJ, Hordijk PL, Tak PP: A Rac1 inhibitory peptide suppresses antibody production and paw swelling in the murine collagen-induced arthritis model of rheumatoid arthritis. Arthritis Res Ther 2010, 12:R2.

2. Hammaker D, Firestein GS: 'Go upstream, young man': lessons learned from the p38 saga. Ann Rheum Dis 2010, 69(Suppl 1):i77-i82.

3. Damjanov N, Kauffman RS, Spencer-Green GT: Efficacy, pharmacodynamics, and safety of VX-702, a novel p38 MAPK inhibitor, in rheumatoid arthritis: results of two randomized, double-blind, placebo-controlled clinical studies. Arthritis Rheum 2009, 60:1232-1241.

4. Weinblatt ME, Kavanaugh A, Burgos-Vargas R, Dikranian AH, Medrano-Ramirez G, Morales-Torres JL, Murphy FT, Musser TK, Straniero N, Vicente-Gonzales AV, Grossbard E: Treatment of rheumatoid arthritis with a Syk kinase inhibitor: a twelve-week, randomized, placebo-controlled trial. Arthritis Rheum 2008, 58:3309-3318.

5. Kremer JM, Bloom BJ, Breedveld FC, Coombs JH, Fletcher MP, Gruben D, Krishnaswami S, Burgos-Vargas R, Wilkinson B, Zerbini CA, Zwillich SH: The safety and efficacy of a JAK inhibitor in patients with active rheumatoid arthritis: results of a double-blind, placebo-controlled phase lla trial of three dosage levels of CP-690,550 versus placebo. Arthritis Rheum 2009, 60:1895-1905.

6. Heasman SJ, Ridley AJ: Mammalian Rho GTPases: new insights into their functions from in vivo studies. Nat Rev Mol Cell Biol 2008, 9:690-701.

7. Yamanishi Y, Boyle DL, Pinkoski MJ, Mahboubi A, Lin T, Han Z, Zvaifler NJ, Green DR, Firestein GS: Regulation of joint destruction and inflammation by p53 in collagen-induced arthritis. Am J Pathol 2002, 160:123-130.

8. Fukushima A, Boyle DL, Corr M, Firestein GS: Kinetic analysis of synovial signaling and gene expression in animal models of arthritis. Ann Rheum Dis 2010. [Epub ahead of print]

doi:10.1186/ar2924

Cite this article as: Firestein GS: 'Rac'-ing upstream to treat rheumatoid arthritis. Arthritis Research \& Therapy 2010, 12:109. 